DOI: $10.15193 /$ zntj/2019/121/314

\author{
AGATA ZNAMIROWSKA, MAGDALENA BUNIOWSKA, \\ KATARZYNA SZAJNAR
}

\title{
ZASTOSOWANIE KONCENTRATU I IZOLATU BIALEK SERWATKOWYCH DO PRODUKCJI MLEKA FERMENTOWANEGO PRZEZ BIFIDOBACTERIUM ANIMALIS SSP. LACTIS BB-12
}

\author{
Streszczenie
}

Mleko fermentowane o zwiększonej zawartości białka może być atrakcyjnym produktem w żywieniu człowieka. Uważa się, że wzrost zapotrzebowania konsumentów na produkty o zwiększonej zawartości białka, w tym napoje, będzie dostrzegalny. Napoje takie mogą być korzystne w dietach o obniżonej wartości energetycznej, ponieważ spożycie energii z białka wydaje się mieć większy wpływ na uczucie sytości niż spożycie tłuszczów lub sacharydów.

Celem pracy było określenie wpływu zagęszczenia mleka do ok. $6 \%$ białka koncentratem (WPC80) lub izolatem białek serwatkowych (WPI) na właściwości fizykochemiczne, sensoryczne, teksturę oraz wzrost Bifidobacterium animals ssp. lactis $\mathrm{Bb}-12$ podczas fermentacji. Próbę kontrolną stanowiło mleko zagęszczone odtłuszczonym mlekiem w proszku (OMP).

Mleko zagęszczono do zawartości $6 \%$ białka przy użyciu OMP, WPC80 lub WPI. Po 10-godzinnej fermentacji $\left(37^{\circ} \mathrm{C}\right)$ istotnie niższe $\mathrm{pH}$ oraz wyższą kwasowość ogólną i zawartość kwasu mlekowego stwierdzono w mleku z dodatkiem WPI i WPC80 w porównaniu do mleka OMP. Zagęszczanie mleka przez dodatek OMP skutkowało istotnym wzrostem twardości, adhezyjności i kleistości. Próbki mleka fermentowanego o zwiększonej zawartości białka (OMP, WPI, WPC80) spełniały kryterium minimum terapeutycznego, tj. zawierały ponad $6 \log$ jtk Bifidobacterium animalis ssp. lactis Bb-12 w $1 \mathrm{~g}$ produktu. Najlepszym stymulatorem wzrostu Bifidobacterium okazał się koncentrat białek serwatkowych (WPC80). Zwiększając zawartość białka w mleku fermentowanym poprzez stosowanie WPI, WPC80, OMP można świadomie kształtować profil smakowy. Zagęszczenie mleka WPC80 skutkowało intensywniejszą fermentacją, wyższą liczbą komórek bakterii $\left(10,52 \log\right.$ jtk $\left.\cdot \mathrm{g}^{-1}\right)$ i zawartością kwasu mlekowego $(0,78 \mathrm{~g} / \mathrm{l})$, co w konsekwencji zintensyfikowało smak kwaśny i zapach fermentacji oraz zmniejszyło odczucie słodkości. Za najkorzystniejszy zamiennik OMP ze względu na cechy sensoryczne mleka fermentowanego uznano izolat białek serwatkowych (WPI).

Słowa kluczowe: mleko fermentowane o zwiększonej zawartości białka, WPI, WPC80, Bifidobacterium

Dr hab. inż. A. Znamirowska, prof. UR., dr inż. M. Buniowska, mgr inż. K. Szajnar, Zaktad Technologii Mleczarstwa, Instytut Technologii Żywności i Żywienia,Uniwersytet Rzeszowski, ul. Ćwiklińskiej 2D, 35-601 Rzeszów.Kontakt:aznam@univ.rzeszow.pl 


\section{Wprowadzenie}

Zgodnie z definicją Codex Alimentarius [6] skoncentrowane mleko fermentowane to fermentowane mleko, w którym zawartość białka przed fermentacją lub po niej została zwiększona do minimum 5,6 \%. Nie ma prawnego standardu definiowania ,jogurtu wysokobiałkowego” czy „mleka fermentowanego wysokobiałkowego”, jednak termin ,skoncentrowane mleko fermentowane” może obejmować zarówno mleko fermentowane, jak i jogurt o podwyższonej zawartości białka. Zwiększoną zawartość białka można uzyskać przed fermentacją przez wzbogacanie mlekiem w proszku, odparowanie lub filtrację membranową, ewentualnie po fermentacji przez odsączanie, separację mechaniczną lub filtrację membranową. Tradycyjnie, odtłuszczone mleko w proszku (OMP) służy do zagęszczania mleka przed fermentacją. Alternatywę dla OMP może jednak stanowić dostępność i jakość innych składników mlecznych. Wśród nich znajdują się koncentraty białek serwatkowych (WPC80) $(34 \div 89 \%$ białka), izolaty (WPI) (>90\% białka) oraz kazeiniany (sole sodowe i amonowe kazeiny), które poprawiają strukturę i właściwości funkcjonalne produktu [20, 33]. Zastosowanie do zagęszczania mleka białek, peptydów i aminokwasów jest korzystniejsze ze względów odżywczych, jednak opublikowane wyniki badań nie są jednoznaczne w odniesieniu do rodzaju i ilości dodatków białkowych, które mogą być stosowane. Badano różne substancje wzbogacające mleko, mające na celu skrócenie czasu fermentacji i poprawę właściwości sensorycznych, głównie jogurtu [19, 23]. Wpływ zastąpienia OMP przez WPC80 lub kazeinian sodu na strukturę, fermentację i właściwości fizyczne jogurtów był także badany $[7,17,22]$. Niektórzy autorzy przedstawili niejednoznaczne wyniki dotyczące biojogurtów [19, 23, 31], lecz niewiele badań poświęcono określeniu wpływu zagęszczenia mleka białkami serwatkowymi na wzrost szczepów probiotycznych i jakość otrzymywanych napojów [16, 35].

Z perspektywy żywieniowej interesujące może być wytwarzanie napojów o zwiększonej zawartości białka z dodatkiem białek serwatkowych [13]. Na świecie oczekuje się dalszego wzrostu zapotrzebowania konsumentów na produkty o zwiększonej zawartości białka [25]. Mleko o zwiększonej zawartości białka może być korzystne $\mathrm{w}$ dietach o obniżonej wartości energetycznej, ponieważ spożycie energii z białka wydaje się mieć większy wpływ na uczucie sytości niż spożycie thuszczów lub węglowodanów [3]. Mleko o zwiększonej zawartości białek serwatkowych może być wykorzystane w żywieniu niemowląt, osób starszych lub uprawiających sport, dzięki zdolności białek serwatkowych do zwiększania stężenia aminokwasów w osoczu i przyczyniania się do syntezy białek mięśniowych $[9,32,36]$.

Celem pracy było określenie wpływu zagęszczania mleka do ok. $6 \%$ białka koncentratem (WPC80) i izolatem (WPI) białek serwatkowych na właściwości fizykochemiczne, sensoryczne, teksturę oraz wzrost Bifidobacterium animals ssp. lactis Bb-12 
podczas fermentacji. Jako próbę kontrolną stosowano mleko zagęszczone odtłuszczonym mlekiem w proszku (OMP).

\section{Material i metody badań}

Do produkcji mleka fermentowanego stosowano: mleko krowie pasteryzowane, mikrofiltrowane o zawartości tłuszczu $2 \%$ (OSM Piątnica, Polska), OMP - odthuszczone mleko w proszku (GM Gostyń), WPC80 - $100 \%$ Natural Whey Protein Concentrate (Olimp, Nagawczyna, Polska) o składzie [g/100 g]: białko - 77, sacharydy -6 , thuszcze - 7, WPI - 100 \% Natural Whey Protein Isolate (Olimp, Nagawczyna, Polska) o składzie [g/100 g]: białko - 87, sacharydy - 1, thuszcze $-0,6$.

Mleko podzielono na trzy porcje. Do pierwszej porcji, jako kontrolnej, dodano mleko w proszku (OMP), do drugiej - koncentrat białek serwatkowych (WPC80), a do trzeciej - izolat białek serwatkowych (WPI) w takiej ilości, aby zapewnić w każdej porcji zawartość białka na poziomie $6 \%$. Skład chemiczny mleka (białko, tłuszcz, laktoza, sucha masa) kontrolowano w analizatorze składu mleka i przetworów Bentley B-150 (Bentley Instruments, USA). Mleko homogenizowano (temp. $65^{\circ} \mathrm{C}, 20 \mathrm{MPa}$ ), pasteryzowano (temp. $85^{\circ} \mathrm{C}, 30 \mathrm{~min}$ ) i chłodzono do temp. $37^{\circ} \mathrm{C}$. Po wychłodzeniu próbki mleka szczepiono $5 \%(\mathrm{v} / \mathrm{v})$ inoculum 24-godzinnej hodowli Bifidobacterium (Bb-12®) (Chr. Hansen, Dania) o liczbie komórek 9,0 log jtk $\cdot \mathrm{g}^{-1}$. Mleko rozlewano do opakowań o pojemności $100 \mathrm{ml}$ z pokrywką i kodowano (OMP, WPC80, WPI). Inkubację prowadzono w temp. $37^{\circ} \mathrm{C}$ przez $10 \mathrm{~h}$. Czas ukwaszania został ustalony na podstawie badań wstępnych i był taki sam we wszystkich doświadczeniach. Po fermentacji próbki mleka schładzano do temp. $5{ }^{\circ} \mathrm{C}$ i przechowywano w tej temperaturze przez 7 dni.

Próbki do analiz pobierano po 7 dniach i oznaczano: pH - przy użyciu pH-metru Toledo FiveEasy TM wyposażonego w elektrodę LE438 ze zintegrowanym czujnikiem temperatury (Mettler Toledo, Szwajcaria), kwasowość ogólną w ${ }^{\circ} \mathrm{SH}$ [27], zawartość kwasu mlekowego zgodnie z wytycznymi Jemai i wsp. [12], a wynik podawano w gramach kwasu mlekowego na litr, synerezę [\%] - metodą wirówkową [15], teksturę - testem TPA (teksturometr Brookfield CT3, Brookfield AMETEK, USA). Wykonywano dwukrotny test penetracyjny przy ustawieniach: siła $-0,1 \mathrm{~N}$, prędkość głowicy $1 \mathrm{~mm} \cdot \mathrm{s}^{-1}$, średnica próbki $-35 \mathrm{~mm}$, sondaTA3/100, średnica elementu pomiarowego 25,3 mm (Brookfield AMETEK, USA). Określano: twardość, adhezyjność, odkształcalność, kleistość, kohezyjność i sprężystość. Ocenę sensoryczną metodą profilowania przeprowadził przeszkolony 15-osobowy zespół [2, 29]. Próbki mleka fermentowanego oceniano w skali 9-stopniowej ze skalą liniową ustrukturowaną i z określeniami brzegowymi: lewy koniec skali oznaczał cechę najmniej wyczuwalną i najmniej charakterystyczną (smak i zapach), bardzo miękką (konsystencja), ciemną (barwa), natomiast prawy - cechę najintensywniejszą i najbardziej charakterystyczną (smak i zapach), 
bardzo zwięzłą (konsystencja), jasną (barwa) [2]. Oceniano konsystencję, barwę, smak mleczno-kremowy, smak kwaśny, smak słodki, zapach jogurtowy, smak i zapach obcy.

Liczbę bifidobakterii określano metodą płytkową. Wysiewy próbek wykonywano w podłożu MRS Agar (Biocorp, Poland), inkubowano w temp. $37{ }^{\circ} \mathrm{C}$ przez $72 \mathrm{~h}$ w warunkach beztlenowych [18]. Do utrzymania warunków beztlenowych używano eksykatora próżniowego oraz GENbox anaer (Biomerieux, Polska), natomiast do kontroli warunków - wskaźnika Anaer indicator (Biomerieux, Polska). Wyniki podawano $w \log j \mathrm{tk} \cdot \mathrm{g}^{-1}$.

Otrzymane wyniki opracowano statystycznie w programie Statistica v.13.1. Przeprowadzono jednoczynnikową analizę wariancji, a istotność różnic między wartościami średnimi szacowano testem Tukeya przy $\mathrm{p}<0,05$. Obliczono współczynniki korelacji liniowej (r) pomiędzy badanymi cechami.

\section{Wyniki i dyskusja}

Mleko fermentowane o podwyższonej zawartości białka można uzyskać przez fortyfikację mleka proszkami mlecznymi, proszkiem serwatkowym, suszoną maślanką oraz koncentratami lub izolatami białek serwatkowych [1]. Uzyskanie pożądanego poziomu białka za pomocą mleka w proszku powoduje jednak zwiększenie zawartości laktozy w produkcie. Na przykład wzbogacenie mleka w białko pochodzące z odtłuszczonego mleka ( $42 \%$ białka, $46 \%$ laktozy) do zawartości białka w mleku fermentowanym w przybliżeniu na poziomie $9 \%$ zwiększyłoby jednocześnie zawartość laktozy do ok. $11 \%[4,24]$. W mleku fermentowanym $\mathrm{z}$ dodatkiem mleka w proszku stwierdzono istotne zwiększenie zawartości laktozy i podwyższony poziom suchej masy $(\mathrm{p}<0,05)-$ tab.1. Nie wykazano natomiast istotnych różnic pod względem składu chemicznego między próbkami mleka zagęszczonego WPI i WPC80. Wszystkie próbki, zgodnie z założeniem, zawierały ok. $6 \%$ białka. Również Agarwal i wsp. [1] stwierdzili, że wzbogacanie mleka w białko poprzez dodatek koncentratów białkowych zapewnia zwiększenie stężenia białka bez znacznego wzrostu zawartości laktozy.

Po 10-godzinnej fermentacji mleka istotnie niższe pH oraz wyższą kwasowość ogólną i zawartość kwasu mlekowego stwierdzono w mleku WPI i WPC80 w porównaniu z OMP $(\mathrm{p}<0,05)$. Również w badaniach Bonga i Moraru [4] zawartość kwasu mlekowego przy końcowym $\mathrm{pH}=4,3$ była znacząco większa w jogurtach $(9,5 \%$ białka) wzbogaconych WPC80 niż w jogurtach z dodatkiem OMP. Jørgensen i wsp. [13] zaobserwowali wydłużony czas fermentacji jogurtu (ok. $8 \%$ białka) wytwarzanego z dodatkiem koncentratu kazeiny w porównaniu z jogurtem o zwiększonych proporcjach białek serwatki do kazeiny. Było to związane ze zwiększonym stężeniem związków buforujących, takich jak: kazeina i koloidalny fosforan wapnia (ang. colloidal calcium phosphate - CCP). Jak podają Salaün i wsp. [30], mleko krów rasy Jersey, w którym stwierdzono większą zawartość białka i fosforanów, cechuje się wyższą zdolnością 
buforowania niż mleko krów rasy holsztyńskiej, co powoduje konieczność wydłużenia czasu fermentacji w celu uzyskania określonej wartości pH w mleku fermentowanym.

Tabela 1. Skład chemiczny mleka zagęszczonego

Table 1. Chemical composition of concentrated milk

\begin{tabular}{||c|c|c|c||}
\hline \hline Składnik / Compound & OMP & WPI & WPC80 \\
\hline Białko / Protein [\%] & $6,03^{\mathrm{a}} \pm 0,03$ & $6,02^{\mathrm{a}} \pm 0,02$ & $6,05^{\mathrm{a}} \pm 0,02$ \\
\hline Tłuszcz / Fat [\%] & $2,04^{\mathrm{c}} \pm 0,00$ & $1,84^{\mathrm{a}} \pm 0,01$ & $1,88^{\mathrm{b}} \pm 0,01$ \\
\hline Laktoza / Lactose [\%] & $8,88^{\mathrm{b}} \pm 0,07$ & $5,84^{\mathrm{a}} \pm 0,01$ & $5,82^{\mathrm{a}} \pm 0,02$ \\
\hline Sucha masa / Dry mass [\%] & $19,90^{\mathrm{b}} \pm 0,03$ & $14,42^{\mathrm{a}} \pm 0,02$ & $14,41^{\mathrm{a}} \pm 0,03$ \\
\hline
\end{tabular}

Objaśnienia / Explanatory notes:

OMP - odtłuszczone mleko w proszku / skimmed milk powder, WPI - izolat białek serwatkowych / whey protein isolate, WPC80 - koncentrat białek serwatkowych / whey protein concentrate. W tabeli przedstawiono wartości średnie \pm odchylenia standardowe / Table shows mean values \pm standard deviations; $\mathrm{n}=15 ; \mathrm{a}, \mathrm{b}-$ wartości średnie oznaczone różnymi literami różnią się statystycznie istotnie $(\mathrm{p}<0,05)$ / Mean values denoted by different letters differ statistically significantly at $(\mathrm{p}<0,05)$.

Stwierdzono istotną korelację liniową pomiędzy zawartością laktozy a $\mathrm{pH}$ $(\mathrm{r}=0,95, \mathrm{p}<0,05)$ i kwasem mlekowym $(\mathrm{r}=-0,97, \mathrm{p}<0,05)$, co wskazuje na intensywniejszy proces fermentacji.

Tabela 2. Kwasowość, synereza i liczba komórek Bifidobactium animalis ssp. lactis Bb-12 w mleku fermentowanym

Table 2. Total acidity, syneresis and count of Bifidobacterium Bb-12 cells in fermented milk

\begin{tabular}{||c|c|c|c||}
\hline Wyróżnik / Parameter & OMP & WPI & WPC80 \\
\hline $\mathrm{pH} / \mathrm{pH}$ values & $4,86^{\mathrm{b}} \pm 0,07$ & $4,70^{\mathrm{a}} \pm 0,06$ & $4,70^{\mathrm{a}} \pm 0,03$ \\
\hline $\begin{array}{c}\text { Kwasowość ogólna } \\
\left.\text { Total acidity [ }{ }^{\circ} \mathrm{SH}\right]\end{array}$ & $32,72^{\mathrm{a}} \pm 1,25$ & $36,55^{\mathrm{b}} \pm 1,34$ & $36,56^{\mathrm{b}} \pm 1,18$ \\
\hline $\begin{array}{c}\text { Kwas mlekowy } \\
\text { Lactic acid [g/l] }\end{array}$ & $0,65^{\mathrm{a}} \pm 0,06$ & $0,75^{\mathrm{b}} \pm 0,05$ & $0,78^{\mathrm{b}} \pm 0,02$ \\
\hline Synereza / Syneresis [\%] & $57,34^{\mathrm{a}} \pm 1,90$ & $69,32^{\mathrm{b}} \pm 1,14$ & $70,41^{\mathrm{b}} \pm 0,87$ \\
\hline $\begin{array}{c}\text { Bifidobacterium } \text { Bb-12 } \\
{\left[\log \text { jtk. }{ }^{-1}\right]}\end{array}$ & $9,85^{\mathrm{a}} \pm 0,63$ & $10,05^{\mathrm{a}} \pm 0,59$ & $10,52^{\mathrm{b}} \pm 0,21$ \\
\hline
\end{tabular}

Objaśnienia jak pod tab. 1. / Explanatory notes as in Tab. 1.

Wzbogacanie mleka izolatem WPI lub koncentratem WPC80 skutkowało otrzymaniem żeli kwasowych o istotnie wyższym stopniu synerezy niż w mleku fermentowanym $\mathrm{z}$ dodatkiem OMP $(\mathrm{p}<0,05)$. Według Bonga i Moraru [4] jogurt wzbogacony koncentratem zawierającym 58 \% białka cechował się większą zdolnością utrzymywania serwatki niż jogurt z dodatkiem koncentratu o zawartości $88 \%$ białka. Tendencję tę 
wyjaśniono większą o ok. 19 \% zawartością suchej masy w jogurcie z dodatkiem koncentratu $\mathrm{w}$ porównaniu $\mathrm{z}$ jogurtem zawierającym $15 \%$ suchej masy wzbogaconym koncentratem o zawartości $88 \%$ białka. Potwierdzają tę zależność także wyniki istotnie większej zawartości suchej masy w próbkach OMP (tab. 1) oraz obliczone współczynniki korelacji. Wykazano istotnie silną zależność pomiędzy synerezą a suchą masą $(\mathrm{r}=-0,99, \mathrm{p}<0,05), \mathrm{pH}(\mathrm{r}=-0,90, \mathrm{p}<0,05)$ i zawartością kwasu mlekowego $(\mathrm{r}=0,97, \mathrm{p}<0,05)$.

Wzbogacanie mleka proszkami OMP, WPI, WPC80 miało wpływ na wzrost liczby Bifidobactium animalis ssp. lactis $\mathrm{Bb}-12 \mathrm{w}$ fermentowanych próbkach mleka o podwyższonej zawartości białka (tab. 2). Najwyższą liczbę komórek stwierdzono $\mathrm{w}$ mleku z dodatkiem koncentratu WPC80. Istotnie niższą liczbę komórek bakterii oznaczono w mleku z OMP i WPI $(\mathrm{p}<0,05)$. Próbki te spełniały kryterium minimum terapeutycznego, czyli liczba komórek bakterii przekraczała 6 log jtk $\cdot \mathrm{g}^{-1}$ [6]. Wpływ różnych kombinacji preparatów białkowych na wzrost bakterii jogurtowych i Bifidobacterium badali Marafon i wsp [20]. Również w tych badaniach wykazano, że najlepszym stymulatorem wzrostu Bifidobacterium był koncentrat białek serwatkowych WPC80 zastosowany wraz z kazeinianem i OMP. W mleku fermentowanym wzbogaconym mieszanką WPC80 z kazeinianem i OMP obserwowano intensywniejszy wzrost bakterii $\left(7,8 \mathrm{log}\right.$ jtk $\left.\cdot \mathrm{ml}^{-1}\right)$ niż w mleku tylko $\mathrm{z}$ dodatkiem OMP $\left(6,91 \mathrm{log} \mathrm{jtk} \cdot \mathrm{ml}^{-1}\right)$. Kozioł i wsp. [16] po przeanalizowaniu wpływu preparatów białkowych na wzrost Bifidobaacterium stwierdzili, że $\alpha$-laktoglobulina i izolat białek serwatkowych wywierały największy wpływ na namnażanie się szczepów Bifidobacterium. Według wielu autorów [13, 14, 34, 35] nadmierne stężenie laktozy może hamować wzrost bakterii mlekowych i zmniejszać szybkość fermentacji mlekowej ze względu na zwiększone ciśnienie osmotyczne. Wykazano, że stężenie laktozy wynoszące $15 \%$ wpływało na zahamowanie wzrostu niektórych szczepów bakterii kwasu mlekowego [34]. W badaniach własnych (tab. 1) wykazano, że już zawartość 8,8 \% laktozy w mleku wpływała hamująco na wzrost Bifidobacterium $(\mathrm{r}=-0,79, \mathrm{p}<0,05)$.

Należy również nadmienić, że bifidobakterie są dobrze przystosowane do wykorzystywania jako źródła węgla sacharydów, głównie poprzez biosyntezę licznych enzymów o zróżnicowanych właściwościach hydrolitycznych. Bifidobakterie fermentują cukry w tzw. szlaku bifidus, którego produktem jest kwas octowy i mlekowy, najczęściej w proporcji $3: 2$, mogą także tworzyć etanol i kwas mrówkowy. Stwierdzono u bifidobakterii występowanie $\beta$-galaktozydazy nawet w postaci kilku izoform [11], co umożliwia wykorzystanie laktozy do fermentacji.

Martinéz i wsp. [22] oraz Marafon i wsp. [20] podkreślili duże znaczenie rodzaju dodanego białka do zagęszczania mleka, zwłaszcza białek serwatkowych, które kształtują strukturę i konsystencję żelu. Zaobserwowali, że jogurty wzbogacone WPC80 
i OMP tworzyły żele o różnej lepkości i poziomie synerezy, co było uzależnione od źródła białka.

Zagęszczenie mleka przez dodatek OMP skutkowało istotnym wzrostem twardości, adhezyjności i kleistości w porównaniu z WPC80 i WPI (tab. 3). O takim rozkładzie wyników zadecydowała w dużym stopniu zawartość suchej masy. Stwierdzono istotną zależność korelacyjną między zawartością suchej masy a twardością $(\mathrm{r}=0,93$, $\mathrm{p}<0,05)$, adhezyjnością $(\mathrm{r}=0,91, \mathrm{p}<0,05)$ oraz kleistością $(\mathrm{r}=0,99, \mathrm{p}<0,05)$. Istotne współczynniki korelacji występowały również pomiędzy wartościami $\mathrm{pH}$ mleka fermentowanego a wymienionymi składowymi tekstury $(\mathrm{r}>0,80, \mathrm{p}<0,05)$.

W badaniach Skrzypczak i Gustawa [31] dodatek OMP do regenerowanego mleka pełnego wpłynął na wzrost twardości jogurtów stałych, a wraz ze zwiększaniem stężenia OMP twardość przyjmowała coraz wyższe wartości. Według Nastaja i wsp. [26] właściwości tekstury jogurtów o zwiększonej zawartości białka wzbogaconych w WPI i WPC80 zależały od rodzaju preparatu białkowego i jego stężenia. Damin i wsp. [7] wykazali zwiększenie twardości jogurtu beztłuszczowego z dodatkiem WPC i OMP w porównaniu z jogurtem WPI. Gustaw i wsp. [8] twierdzą natomiast, że wzrost stężenia preparatów białek mleka nie powodował w większości przypadków istotnych różnic w twardości skrzepów kwasowych. Chever i wsp. [5] stwierdzili natomiast większą twardość żelu mleka ukwaszonego z dodatkiem kazeinianu wapnia w porównaniu z żelami, w których część kazeinianu wapnia zastąpiono izolatem białka serwatkowego.

Sprzeczne wyniki badań mogą wynikać z różnej zawartości białka w porównywanych, zróżnicowanych próbkach mleka fermentowanego. Możliwym wyjaśnieniem tego zjawiska jest niekorzystny stosunek białka serwatki do kazeiny oraz niski stopień denaturacji białek serwatki, które powodują, że tylko niewielka część miceli kazeiny pokryta była zdenaturowanymi białkami serwatki. Gdy pH osiągnęło wartość punktu izoeletrycznego miceli kazeiny ( $\mathrm{pI}=4,6)$, ich agregacja nastąpiła głównie w wyniku zmniejszonego ujemnego ładunku netto tych miceli [10, 13]. Patocka i wsp. [28] po dodaniu białek serwatkowych i fermentacji jogurtu zaobserwowali szybki rozpad żelu jogurtowego, w wyniku czego powstały dwie oddzielne fazy zawierające płynną serwatkę i masę białkową. W przeprowadzonym doświadczeniu własnym nie zaobserwowano rozdzielenia fazy płynnej i stałej.

Normalizacja zawartości białka za pomocą WPC80 lub WPI wpłynęła na zwiększenie wartości odkształcalności i kohezyjności oraz obniżenie adhezyjności i kleistości żelu kwasowego w porównaniu z mlekiem OMP. Zastosowane dodatki białkowe nie wpłynęły natomiast na sprężystość mleka fermentowanego. 
Tabela 3. Tekstura mleka fermentowanego

Table 3. Texture of fermented milk

\begin{tabular}{|c|c|c|c||}
\hline Wyróżnik / Parameter & OMP & WPI & WPC80 \\
\hline Twardość / Hardness [N] & $0,65^{\mathrm{b}} \pm 0,07$ & $0,37^{\mathrm{a}} \pm 0,07$ & $0,28^{\mathrm{a}} \pm 0,08$ \\
\hline Adhezyjność / Adhesiveness [mJ] & $0,62^{\mathrm{b}} \pm 0,43$ & $0,16^{\mathrm{a}} \pm 0,05$ & $0,18^{\mathrm{a}} \pm 0,08$ \\
\hline Odkształcalność / Resilience & $0,18^{\mathrm{a}} \pm 0,07$ & $0,69^{\mathrm{b}} \pm 0,12$ & $0,89^{\mathrm{c}} \pm 0,05$ \\
\hline Kleistość / Stickiness [mm] & $7,49^{\mathrm{b}} \pm 1,39$ & $4,00^{\mathrm{a}} \pm 0,43$ & $3,80^{\mathrm{a}} \pm 0,88$ \\
\hline Kohezyjność / Cohesiveness & $0,60^{\mathrm{a}} \pm 0,09$ & $0,86^{\mathrm{b}} \pm 0,09$ & $0,98^{\mathrm{b}} \pm 0,05$ \\
\hline Sprężystość / Springiness [mm] & $14,15^{\mathrm{a}} \pm 0,58$ & $14,15^{\mathrm{a}} \pm 0,56$ & $14,18^{\mathrm{a}} \pm 0,45$ \\
\hline
\end{tabular}

Objaśnienia jak pod tab. 1. / Explanatory notes as in Tab. 1.

Tabela 4. Wyniki oceny sensorycznej mleka fermentowanego

Table 4. Results of sensory evaluation of fermented milk

\begin{tabular}{||c|c|c|c||}
\hline \hline Cecha / Attribute & OMP & WPI & WPC80 \\
\hline Konsystencja / Consistency & $7,80^{\mathrm{b}} \pm 0,63$ & $6,70^{\mathrm{b}} \pm 1,49$ & $4,10^{\mathrm{a}} \pm 0,79$ \\
\hline Barwa / Colour & $7,60^{\mathrm{b}} \pm 1,07$ & $5,30^{\mathrm{a}} \pm 1,42$ & $5,30^{\mathrm{a}} \pm 1,57$ \\
\hline $\begin{array}{c}\text { Smak mleczno-kremowy } \\
\text { Milky-cream flavour }\end{array}$ & $6,80^{\mathrm{c}} \pm 1,93$ & $4,20^{\mathrm{b}} \pm 0,92$ & $2,40^{\mathrm{a}} \pm 1,07$ \\
\hline Smak kwaśny / Sour taste & $1,90^{\mathrm{a}} \pm 1,10$ & $5,50^{\mathrm{b}} \pm 1,43$ & $7,60^{\mathrm{c}} \pm 2,17$ \\
\hline Smak słodki / Sweet taste & $6,60^{\mathrm{c}} \pm 1,36$ & $4,80^{\mathrm{b}} \pm 1,23$ & $1,70^{\mathrm{a}} \pm 0,25$ \\
\hline $\begin{array}{c}\text { Smak obcy } \\
\text { Strange taste, metallic taste }\end{array}$ & $1,20^{\mathrm{a}} \pm 0,20$ & $2,60^{\mathrm{b}} \pm 0,97$ & $4,40^{\mathrm{c}} \pm 1,08$ \\
\hline $\begin{array}{c}\text { Zapach fermentacji } \\
\text { Fermentation smell }\end{array}$ & $2,30^{\mathrm{a}} \pm 1,42$ & $3,00^{\mathrm{ab}} \pm 1,25$ & $4,80^{\mathrm{b}} \pm 1,15$ \\
\hline $\begin{array}{c}\text { Zapach obcy } \\
\text { Strange smell }\end{array}$ & $1,00^{\mathrm{a}} \pm 0,00$ & $1,50^{\mathrm{a}} \pm 0,50$ & $1,50^{\mathrm{a}} \pm 0,50$ \\
\hline
\end{tabular}

Objaśnienia / Explanatory notes:

$\mathrm{n}=45$. Pozostałe objaśnienia jak pod tab. 1. / Other explanatory notes as in Tab. 1.

W opinii zespołu oceniającego próbki mleka z dodatkiem OMP cechowały się bardziej zwięzłą konsystencją, jaśniejszą barwą, intensywniejszym smakiem słodkim i mleczno-kremowym niż próbki wzbogacone WPI i WPC80. Konsystencję w dużym stopniu kształtowała zawartość suchej masy $(\mathrm{r}=0,77, \mathrm{p}<0,05)$ i $\mathrm{pH}(\mathrm{r}=0,70$, $\mathrm{p}<0,05)$, natomiast smak słodki i mleczno-kremowy mleka fermentowanego uzależniony był od stężenia laktozy $(\mathrm{r}>0,75, \mathrm{p}<0,05)$ i zawartości kwasu mlekowego $(\mathrm{r}>-0,83, \mathrm{p}<0,05)$ Dodatek WPC80 skutkował intensywniejszą fermentacją i wyższą liczbą komórek bakterii oraz większą zawartością kwasu mlekowego, co w konsekwencji zintensyfikowało smak kwaśny i zapach fermentacji oraz zmniejszyło zawartość laktozy, marginalizując odczucie słodkości. W mleku wzbogaconym WPI i WPC80 wykazano smak i zapach obcy. Najbardziej intensywny smak obcy definio- 
wany przez oceniających jako posmak gotowania i tektury stwierdzono w mleku $z$ dodatkiem WPC80 (tab. 4). Jak podają Jørgensen i wsp. [14], profile smakowe komercyjnych koncentratów białek serwatkowych różnią się w zależności od zawartości białka, nadając posmak płatków zbożowych, gotowania i uczucie cierpkości w ustach.

Wyższe końcowe pH po fermentacji $($ ok. 4,8$)$ może pozytywnie wpływać na cechy jogurtu o zwiększonej zawartości białka ze względu na mniej kwaśny smak i gładszą konsystencję jogurtu [17, 21]. W przeprowadzonych badaniach mleko z dodatkiem OMP cechowało się istotnie wyższą wartością $\mathrm{pH}$ niż mleko wzbogacone w WPI i WPC80 (tab. 2), co również wpłynęło na wyniki oceny konsystencji (tab. 4). Jørgensen i wsp. [14] proponują zatrzymanie fermentacji jogurtów o zwiększonej zawartości białka w celu niedopuszczenia do dalszego obniżania poziomu $\mathrm{pH}$ produktu. Interesującym pomysłem może być działanie zmierzające do zmniejszenia ziarnistej struktury i kwaśnego smaku.

\section{Wnioski}

1. Próby mleka fermentowanego o podwyższonej zawartości białka (OMP, WPI, WPC80) spełniają kryterium minimum terapeutycznego, tj. zawierają ponad $6 \log$ $\mathrm{jtk} \cdot \mathrm{g}^{-1}$ Bifidobacterium animalis ssp. lactis $\mathrm{Bb}-12$.

2. Najlepszym stymulatorem wzrostu Bifidobacterium jest koncentrat białek serwatkowych WPC80.

3. Poprzez stosowanie WPI, WPC80, OMP do zwiększania zawartości białka w mleku fermentowanym można kształtować jego profil smakowy.

4. Najkorzystniejszym zamiennikiem OMP ze względu na cechy sensoryczne mleka fermentowanego jest izolat białek serwatkowych.

\section{Literatura}

[1] Agarwal S., Beausire R.L., Patel S., Patel H.: Innovative uses of milk protein concentrates in product development. J. Food Sci., 2015, 80, A23-A29.

[2] Baryłko-Pikielna N., Matuszewska I.: Sensoryczne badania żywności. Podstawy. Metody. Zastosowania. Wyd. II. Wyd. Nauk. PTTŻ, Kraków 2014.

[3] Benelam B.: Satiation, satiety and their effects on eating behaviour. Nutrition Bulletin, 2009, 34, 126-173.

[4] Bong D.D., Moraru C.I.: Use of micellar casein concentrate for Greek-style yogurt manufacturing: Effects on processing and product properties. J. Dairy Sci., 2014, 97, 1259-1269.

[5] Chever S., Guyomarch F., Beaucher E., Famelart M.H.: High-protein fat-free acid milk gels: Control of protein composition and heat treatment. Int. Dairy J., 2014, 37, 95-103.

[6] Codex Alimentarius: Milk and milk products. WHO and FAO, Rome, 2011, pp. 6-7.

[7] Damin M.R., Alcantara M.R., Nunes A.P., Oliveira M.N.: Effects of milk supplementation with skim milk powder, whey protein concentrate and sodium caseinate on acidification kinetics, rheolog- 
ical properties and structure of nonfat stirred yogurt. LWT - Food Sci. Technol., 2009, 42 (10), 1744-1750.

[8] Gustaw W., Kozioł J., Waśko A., Skrzypczak K., Michalak-Majewska M., Nastaj M.: Właściwości fizykochemiczne i przeżywalność Lactobacillus casei w mlecznych napojach fermentowanych otrzymanych z dodatkiem wybranych preparatów białek mleka. Żywność. Nauka. Technologia. Jakość, 2015, 6 (103), 129-139.

[9] Hall W.L., Millward D.J., Long S.J., Morgan L.M.: Casein and whey exert different effects on plasma amino acid profiles, gastrointestinal hormone secretion and appetite. Brit. J. Nutr., 2003, 89, 239248.

[10] Huppertz T., Fox P.F., Kelly A.L.: The caseins: Structure, stability and functionality. In: Proteins in food processing. $2^{\text {nd }}$ ed. Ed. R.Y. Yada. Woodhead Publishing, Cambridge, UK, 2018, 49-92.

[11] Jędrzejczak-Krzepkowska M., Bielecki S.: Bifidobakterie i stymulujące ich wzrost fruktany typu inuliny. Post Bioch., 2011, 57 (4), 392-399.

[12] Jemaa M.B., Falleh H., Neves M.A., Isoda H., Nakajima M., Ksouri R.: Quality preservation of deliberately contaminated milk using thyme free and nanoemulsified essential oils. Food Chem., 2017, 217, 726-734.

[13] Jørgensen C.E., Abrahamsen R.K., Rukke E., Johansen A., Schuller R.B., Skeie S.B.: Improving structure and rheology of high protein, low fat yoghurt with undenatured whey proteins. Int. J. Dairy Technol., 2015, 47, 6-18.

[14] Jørgensen C.E., Abrahamsen R.K., Rukke E.O., Hoffmann T.H., Johansen A.G., Skeie S.B.: Processing of high-protein yoghurt - a review. Int. Dairy J., 2019, 88, 42-59.

[15] Keogh M.K., O'Kennedy B.T.: Rheology of stirred yogurt as affected by added milk fat, protein and hydrocolloids. J. Food Sci., 1998, 63 (1), 108-112.

[16] Kozioł J., Skrzypczak K., Gustaw W., Waśko A.: Wpływ preparatów białek mleka na wzrost bakterii z rodzaju Bifidobaacterium. Żywność. Nauka. Technologia. Jakość, 2013, 3 (88), 83-98.

[17] Kücükcetin A.: Effect of heat treatment and casein to whey protein ratio of skim milk on graininess and roughness of stirred yoghurt. Food Res. Int., 2008, 41, 165-171.

[18] Lima K.G., Kruger M.F., Behrens J., Destro M.T., Landgraf M., Franco B.D.G.: Evaluation of culture media for enumeration of Lactobacillus acidophilus, Lactobacillus casei and Bifidobacterium animalis in the presence of Lactobacillus delbrueckii subsp. bulgaricus and Streptococcus thermophilus. LWT - Food Sci. Technol., 2009, 42, 491-495.

[19] Lucas A., Sodini I., Monnet C., Jolivet P., Corrieu G.: Effect of milk base and starter culture on acidification, texture, and probiotic cell counts in fermented milk processing. J. Dairy Sci., 2004, 85, 2479-2488.

[20] Marafon A.P., Sumi A., Alcântara M.R. Tamime A.Y., de Oliveira M.N.: Optimization of the rheological properties of probiotic yoghurts supplemented with milk proteins. LWT - Food Sci. Technol., 2011, 44 (2), 511-519.

[21] Martin N.C., Skokanova J., Latrille E., Beal C., Corrieu G.: Influence of fermentation and storage conditions on the sensory properties of plain low fat stirred yogurts. J. Sens. Stud., 1999, 14, 139160.

[22] Martinéz C.G., Becerra M., Cháfer M., Albor A., Carot J.M., Chiralt A.: Influence of substituting milk powder for whey powder on yogurt quality. Food Sci. Technol., 2003, 13, 334-340.

[23] McComas K.A., Gilliland S.E.: Growth of probiotic and traditional yogurt cultures in milk supplemented with whey protein hydrolysate. J. Food Sci., 2003, 68, 2090-2095.

[24] Meletharayil G.H., Patel H.A., Huppertz T.: Rheological properties and microstructure of high protein acid gels prepared from reconstituted milk protein concentrate powders of different protein contents. Int. Dairy J., 2015, 47, 64-71. 
[25] Mellentin J.: 10 key trends in food, nutrition \& health 2017. New Nutrition Business, London, UK, 2016.

[26] Nastaj M., Sołowiej B.G., Gustaw W., Peréz-Huertas S., Mleko S., Wesołowska-Trojanowska M.: Physicochemical properties of high-protein-set yoghurts obtained with the addition of whey protein preparations. Int. J. Dairy Technol., 2019, 72 (3), 395-402.

[27] Pachołek B., Żmudziński W., Posiadłowska J.: Towaroznawstwo żywności. Wyd. III. Wyd. UE, Poznań 2015.

[28] Patocka G., Cervenkova R., Narine S., Jelen P.: Rheological behaviour of dairy products as affected by soluble whey protein isolate. Int. Dairy J., 2006, 16, 399-405.

[29] PN-ISO 11035:1999. Analiza sensoryczna. Identyfikacja i wybór deskryptorów do ustalania profilu sensorycznego z użyciem metod wielowymiarowych.

[30] Salaün F., Mietton B., Gaucheron F.: Buffering capacity of dairy products. Int. Dairy J., 2005, 15 (2), 95-109.

[31] Skrzypczak K., Gustaw W.: Wpływ dodatku prebiotyków i białek serwatkowych na właściwości fizykochemiczne biojogurtów. Żywność. Nauka. Technologia. Jakość, 2012, 5 (84), 155-165.

[32] Tipton K.D., Elliott T.A., Cree M.G., Aarsland A.A., Sanford A.P., Wolfe R.R.: Stimulation of net muscle protein synthesis by whey protein ingestion before and after exercise. Am. J. PhysiolEndocrinol. Metab., 2007, 292(1), E71-E76.

[33] Vasiljevic T., Shah N.P.: Probiotics - from Metchnikoff to bioactives. Int. Dairy J., 2008, 18, 714728.

[34] Vedamuthu E.R.: Starter cultures for yoghurt and fermented milks. In: Manufacturing Yogurt and Fermented Milks. Eds. R.C. Chandan, C.H. White, A. Kilara, Y.H. Hui. Blackwell Publishing Professional, Ames, IA, USA, 2006, pp. 93-119.

[35] Vinderola C.G., Costa G.A., Regenhardt S., Reinheimer J.A.: Influence of compounds associated with fermented dairy products on the growth of lactic acid starter and probiotic bacteria. Int. Dairy J., 2002, 12 (7), 579-589.

[36] Zimecki M., Artym J.: Właściwości terapeutyczne białek i peptydów z siary i mleka. Postępy Hig. Med. Dośw., 2005, 59, 309-323.

\title{
APPLICATION OF WHEY PROTEIN CONCENTRATE AND ISOLATE IN THE PRODUCTION OF MILK FERMENTED BY BIFIDOBACTERIUM ANIMALIS SSP. LACTIS BB-12
}

\author{
S u m m a ry
}

Fermented milk with an increased protein content could be an attractive product for human nutrition. It is believed that there would be a noticeable increase in the demand for products with higher protein content including beverages. Such beverages can be beneficial when used in calories-reduced diets because the intake of energy from the protein seems to have a greater effect on the feeling of satiety than the intake of fat or carbohydrates.

The objective of the research study was to determine the effect of concentrating milk to approx. $6 \%$ of protein with a concentrate (WPC80) and whey protein isolate (WPI) on the physicochemical and sensory properties of Bifidobacterium animalis ssp. lactis $\mathrm{Bb}-12$, and on its texture and growth during fermentation. The control sample was milk concentrated by skimmed milk powder (OMP).

The milk was concentrated to a protein content of $6 \%$ using OMP or WPC80, or WPI. After 10-hour fermentation $\left(37^{\circ} \mathrm{C}, 10\right.$ hours $)$ there were determined a significantly lower $\mathrm{pH}$ value and a higher total acidity and lactic acid content in milk with WPI and WPC80 added compared to the OMP milk. Concen- 
trating milk by adding OMP resulted in a significant increase in hardness, adhesiveness and stickiness. The fermented milk samples containing an increased amount of protein (OMP, WPI, WPC80) met the minimum therapeutic criterion, i.e. they contained more than $6 \log$ of Bifidobacterium animalis ssp. lactis $\mathrm{Bb}-12$ in $1 \mathrm{~g}$ of the product. The best stimulator of the Bifidobacterium growth was the concentrate of whey proteins (WPC80). By increasing the protein content in fermented milk using WPI, WPC80, OMP it is possible to knowingly shape the taste profile. Concentrating milk with WPC80 resulted in a more intensive fermentation, a higher count of bacterial cells $\left(10.52 \log \mathrm{CFU} \cdot \mathrm{g}^{-1}\right)$ and in lactic acid content $(0.78 \mathrm{~g} / \mathrm{l})$, and as a consequence this intensified the acidic taste and smell of fermentation and reduced the sensation of sweetness. The whey protein isolate (WPI) was found to be the most advantageous replacement for OMP owing to the sensory characteristics of fermented milk.

Key words: fermented milk with increased content of protein, WPI, WPC80, Bifidobacterium 